\title{
Reviewing putative industrial triggering in pemphigus: cluster of pemphigus in the area near the wastewater treatment plant
}

\author{
Paweł Pietkiewicz' ${ }^{1}$ Justyna Gornowicz-Porowska1, Paweł Bartkiewicz'1 ${ }^{1}$ Monika Bowszyc-Dmochowska², \\ Marian Dmochowski ${ }^{1}$
}

\begin{abstract}
${ }^{1}$ Autoimmune Blistering Dermatoses Section, Department of Dermatology, Poznan University of Medical Sciences, Poznan, Poland ${ }^{2}$ Cutaneous Histopathology and Immunopathology Section, Department of Dermatology, Poznan University of Medical Sciences, Poznan, Poland
\end{abstract}

Adv Dermatol Allergol 2017; XXXIV (3): 185-191

DOI: https://doi.org/10.5114/ada.2017.67840

\begin{abstract}
A range of pemphigus is relatively rare potentially fatal group of autoimmune blistering dermatoses. Usually, there is no apparent triggering, while in some predisposed patients there are alleged environmental/industrial inducing factors. In a short time period (4 years), we diagnosed 3 novel cases of pemphigus (1 pemphigus vulgaris, 1 pemphigus foliaceus and 1 shift from pemphigus foliaceus into pemphigus vulgaris) at a clinical and laboratory level (ELISA, immunofluorescence studies). We discuss a possible common inducing mechanism as these patients inhabit one estate of the Poznan suburbia (Kozieglowy, population <12,000), Greater Poland district, Poland, and review literature data on alleged pemphigus triggers. To the best of our knowledge, this is the first report exploring the putative association between pemphigus diseases and wastewater treatment plant waterborne or volatile by-products in the vicinity of such a facility.
\end{abstract}

Key words: industrial dermatoses, mercaptans, pemphigus, sewage treatment plant.

\section{Introduction to the issue of pemphigus triggering}

Pemphigus belongs to autoimmune blistering dermatoses (ABD). The commonest entities of these are pemphigus vulgaris (PV) and pemphigus foliaceus (PF), severe chronic and relapsing life-threatening disorders requiring individualized immunosuppressive medications [1]. Desmoglein 3 and 1 (DSG3, DSG1) - desmosomal cadherins, participate in epithelial cells adhesion as well as signalling pathways regulating keratinocyte proliferation and differentiation [2-6]. The autoantibodies to these proteins lead to desmosomal adhesion loss, acantholysis and suprabasal blister formation in the skin and mucous membranes by decreasing DSG3/ DSG1 half-life and inducing their cleavage $[7,8]$. Yearly pemphigus incidence in Europe is estimated to be ca. $1 /$ million population [9-12], yet still a possible restriction to relatively well-defined geographic areas (endemic form of pemphigus) is noted in the world (e.g.
Brazil, Colombia, Tunisia). Commonly, there is no apparent inducing factor and the lesions appear spontaneously, while in some patients the medical history gives some clues on potential and/or not infrequently alleged triggers. The aetiology of autoimmunity in ABD seems to be multifactorial, combining both inducing and predisposing factors ("the seed and the soil" theory) [13], and is yet not well understood being largely speculative. Among all those divergent factors, genetic predisposition, physical agents, infections, hormonal disorders, malignancies, emotional stress, various drugs and chemical compounds are listed [13-16]. There have been reports indicating a possible role of environmental/industrial factors in the development of pemphigus in predisposed individuals [13]. Chemical factors that seem to be culprits are: chronic methyl mercury poisoning [16], inhaled silica dust [17-19], inhaled/topical pesticides [20-22], topical insecticides [23], topical or ingested thiols, amides, phenols and miscellaneous drugs $[13,15,24]$.

Address for correspondence: Paweł Pietkiewicz MD, PhD, Autoimmune Blistering Dermatoses Section, Department of Dermatology, Poznan University of Medical Sciences, Heliodor Swiecicki University Hospital, 49 Przybyszewski St, 60-355 Poznan, Poland, phone: +48 6186913 19, e-mail: p.pietkiewicz@mp.pl Received: 26.02.2016, accepted: 1.07.2016. 

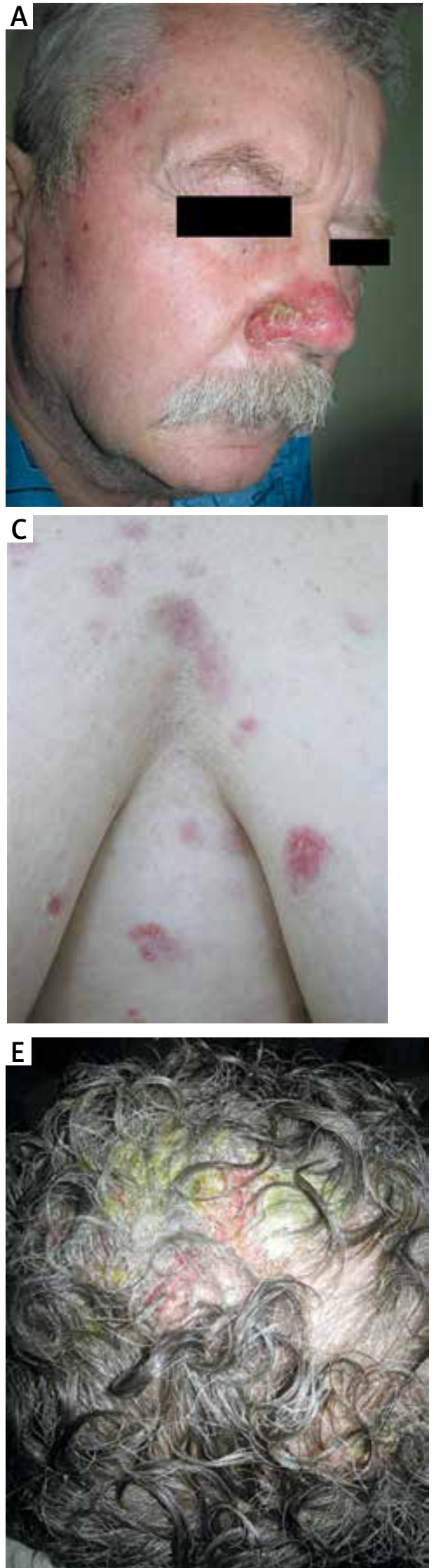
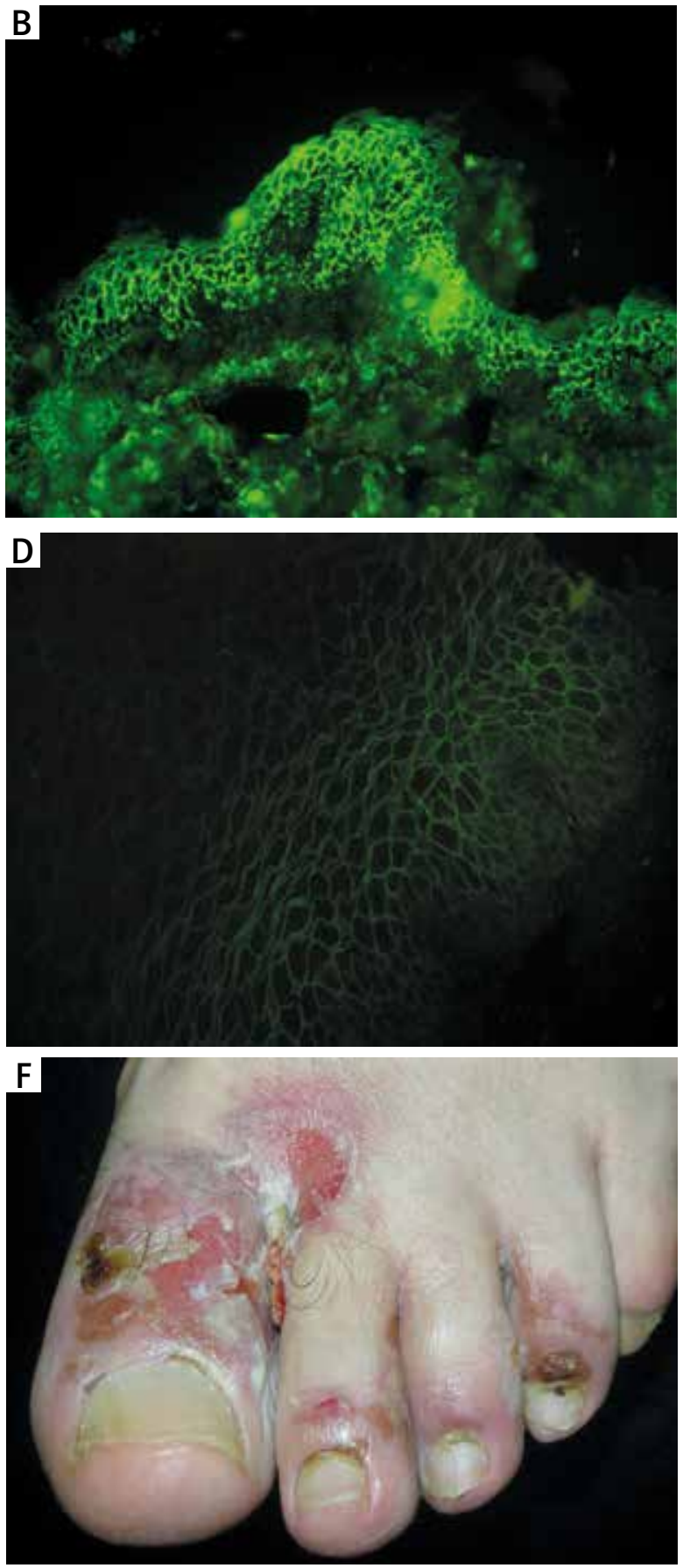

Figure 1. Clinical and laboratory features of patients with pemphigus living near the wastewater treatment plant. A - Pemphigus foliaceus crusted erosion on erythematous base located on the nose of patient no. 1. B - Direct immunofluorescence on perilesional skin showing lgG4 pemphigus deposits in patient no. 1. C - Initial pemphigus foliaceus erosions and erythematous patches on the chest of female patient no. 2. D - Indirect immunofluorescence on monkey esophagus revealing IgG4 pemphigus antibodies in patient no. 2. E-Pemphigus vulgaris crusted erosions with massive impetiginisation on the scalp in patient no. 3 . $\mathrm{F}$ - Pemphigus vulgaris lesions affecting interdigital spaces imitating fungal infection in patient no. 3 
Table 1. Clinical and laboratory features of patients with pemphigus living near the wastewater treatment plant

\begin{tabular}{|c|c|c|c|}
\hline $\begin{array}{l}\text { Patient no./ } \\
\text { sex }\end{array}$ & Diagnosis & DIF & ELISA IgG \\
\hline $1 /$ male & $\mathrm{PF}$ & $\begin{array}{l}\text { Pemphigus deposits of } \operatorname{lgG} 4(+++), C 3(+) \text {. } \\
\text { No deposits of } \operatorname{lgA} \text {, IgM, } \operatorname{lgG} \text { and } \lg G 1\end{array}$ & $\begin{array}{l}\text { Anti-DSG1 > } 150 \mathrm{AU} / \mathrm{ml} \text { (cut-off value } 41 \mathrm{AU} / \mathrm{ml} \text { ) } \\
\text { Anti-DSG3 3.97 AU/ml (cut-off value } 40 \mathrm{AU} / \mathrm{ml} \text { ) }\end{array}$ \\
\hline 2/female & $\mathrm{PF} \rightarrow \mathrm{PV}$ & $\begin{array}{l}\text { Pemphigus deposits of } \operatorname{lgG} 4(++) \text {. No deposits } \\
\text { of } \operatorname{lgA} \text {, IgM, } \operatorname{lgG}, \operatorname{lgG} 1 \text { and } \mathrm{C3}\end{array}$ & $\begin{array}{c}\text { Initially: anti-DSG1 } 200 \mathrm{RU} / \mathrm{ml} \text { (cut-off value } 20 \mathrm{RU} / \mathrm{ml} \text { ), } \\
\text { anti-DSG3 } 5.93 \mathrm{RU} / \mathrm{ml} \text { (cut-off value } 20 \mathrm{RU} / \mathrm{ml} \text { ) } \\
\text { Follow-up: anti-DSG1 0.0 RU/ml (cut-off value } 20 \mathrm{RU} / \mathrm{ml} \text { ), } \\
\text { anti-DSG3 } 56.052 \mathrm{RU} / \mathrm{ml} \text { (cut-off value } 20 \mathrm{RU} / \mathrm{ml} \text { ) }\end{array}$ \\
\hline 3/male & PV & $\begin{array}{l}\text { Pemphigus deposits of } \operatorname{lgG}(+/-) \text {, } \operatorname{lgG} 4(++) \text {, } \\
\mathrm{C} 3(++) \text {. No deposits of } \operatorname{lgA}, \operatorname{lgM} \text { and } \operatorname{lgG} 1\end{array}$ & $\begin{array}{l}\text { Anti-DSG1 } 121.668 \mathrm{RU} / \mathrm{ml} \text { (cut-off value } 20 \mathrm{RU} / \mathrm{ml} \text { ) } \\
\text { Anti-DSG3 > } 200 \mathrm{RU} / \mathrm{ml} \text { (cut-off value } 20 \mathrm{RU} / \mathrm{ml} \text { ) }\end{array}$ \\
\hline
\end{tabular}

$A U$ - arbitrary unit, DIF - direct immunofluorescence, DSG - desmoglein, ELISA - enzyme-linked immunosorbent assay, Ig - immunoglobulin, PF - pemphigus foliaceus, $P V$ - pemphigus vulgaris, $R U$ - relative unit.

\section{Clinical and laboratory features of pemphigus patients living near the wastewater treatment plant}

Clinical examination and single-step direct immunofluorescence of perilesional skin using FITC-conjugated antibodies to human IgA, IgM, IgG, IgG1, IgG4 and C3 for the evaluation of pattern and intensity of deposits of immunoreactants [25] as well as semiquantitative ELISA (MBL, Japan, levels in AU/ml or Euroimmun, Germany, levels in $\mathrm{RU} / \mathrm{ml}$ ) for serum lgG antibodies to DSG1 and DSG3 were used to diagnose pemphigus. In a relatively short time period (4 years), in our university department we diagnosed 3 novel cases of pemphigus (1 PV, 1 PF and 1 shift PF $\rightarrow$ PV) (Figure 1, Table 1) living near the wastewater treatment plant. These middle-aged patients ( 2 men and 1 woman) were not related to one another and had nothing in common, apart from inhabiting one estate of the Poznan suburbia (Kozieglowy, population < 12,000), Greater Poland district, Poland. The female patient with the shift PF $\rightarrow$ PV diagnosed as the first pemphigus case of the three had a stubborn course of her pemphigus which was clinically active at the time of diagnosis of the remaining pemphigus cases. All patients are currently doing well on supportive treatment with oral methylprednisolone or oral methylprednisolone combined with oral dapsone.

\section{Discussion of the issue of pemphigus triggering in relation to a cluster of pemphigus in the vicinity of the wastewater treatment plant}

Living in the vicinity of the wastewater treatment plant and data of the measurement of concentration of substances incriminated to be pemphigus triggers in the air around the plant are the only hints we have concerning the evidence of exposure to the substances originating from this particular plant. Nonetheless, any in vivo provocation test as a conceivable method to get more definitive data regarding plausible industrial triggering with substances incriminated is unadvisable due to lifethreatening nature of pemphigus. Importantly, since the installation of protective domes over sludge tanks (Fig- ure 2), no new cases of pemphigus have been diagnosed in the Kozieglowy estate. Concerning the relative rarity of pemphigus type of dermatoses, the diagnosis of 2 novel cases from one estate in a short time period could be regarded purely coincidental, yet 3 novel cases led us to take a look at a possible common "seed". Due to proximity of the wastewater treatment plant (ca. $1 \mathrm{~km}$ ) to the housing estate located uphill $30 \mathrm{~m}$ above the level of the settlement tanks, considering the prevalence of western winds in the Greater Poland district [26] and terrain characteristics (slope, natural forest barrier limiting the eastern winds in the area), we suspect a common factor - presumably waterborne and/or volatile waste products. Volatile organic compounds may be dangerous for wastewater treatment plant workers and inhabitants of nearby houses $[27,28]$. The highest levels of these compounds are emitted by a primary clarifier, while the concentration of selected chemicals in one reported case exceeded the regulatory threshold limit even within up to $4 \mathrm{~km}$ distance from the wastewater treatment plant [28].

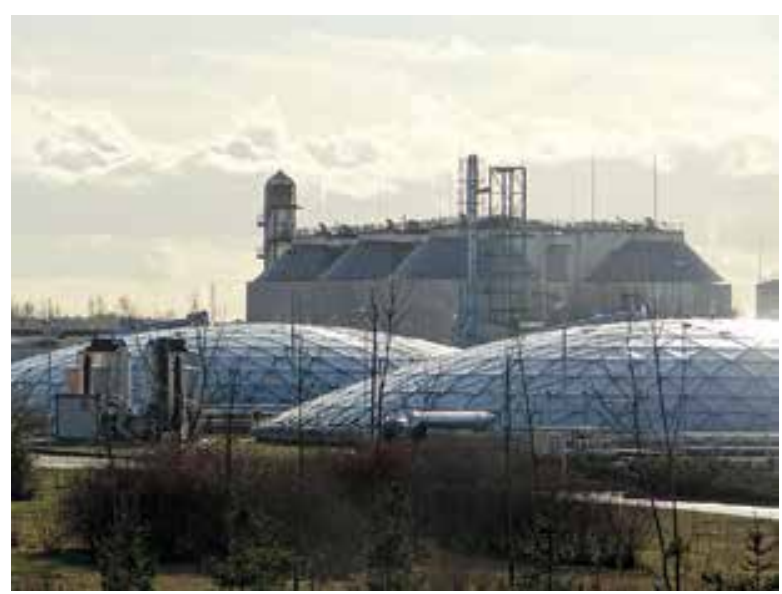

Figure 2. Wastewater treatment plant in Kozieglowy, Greater Poland district, Poland. The sludge tanks are now, after a lengthy print and electronic media campaign, covered with protective domes to reduce the malodor and prevent environmental mishaps 
There are theories attributing a causative role of chemical compounds in triggering/sustaining autoimmunity to their functional groups, but the precise mechanisms of action still remain to be elucidated and experimentally verified. Despite no scientific data on industrial waste-induced pemphigus, many chemical compounds were reported to induce both PV and PF, whereas the pemphigus-pollution issue is raised incidentally in nonscientific press [29-31]. Such alleged association was also suspected in court by an Australian patient formerly working as a garbage collector [32, 33]. Moreover, there is one old case report on a fatal case of acute pemphigus after putrid eel consumption (presumably due to amides) $[34,35]$. Analyzing the composition of sewage, sewage gas and leachate, there are several chemical compounds that are either amides, phenolic compounds, volatile organosulfur compounds (thiols/mercaptans), sulfones or their "masked" forms that could hypothetically contribute to pemphigus pathogenesis [36-39]. Several theories were coined to give an explanation to the assumable mechanisms of chemical compound-driven autoimmunity in PV/PF. It may be suspected that the active radicals of chemical compounds or their metabolites may bind proteins to form haptens triggering $\mathrm{T}$ - and B-lymphocyterelated autoimmunity or alter desmosomal proteins thus giving birth to neoantigens [15].

Phenol derivatives were reported to induce acantholysis both in vitro and in vivo, after topical application and consumption [24, 40,41]. The role of polyphenolic compounds - tannins, contained in food or water, was suggested in research articles and case reports describing fogo selvagem ("wild fire") endemic PF [41-45]. Such phenol derivatives include liquid diphenyl sulphide [36] and various synthetic phenolic antioxidants (e.g. butylated hydroxytoluene (BHT)) [46-50]. Contemporarily, the reports on BHT and its metabolites' disruptive activity on the human and animal endocrine system lead to focusing on better assessment and measures to lower the concentration of these compounds in ground water and sewage [47-49, 51]. Apart from the chemical structure of these phenolic compounds, they are characterized by mostly estrogenic activity. Although there is no proven sex-relation reported in either PV or PF, there were single cases indicating the possible association [52]. Due to lifestyle changes in Western countries including increased use of contraceptives (e.g. ethinylestradiol), and in creased use of phosphorus organic pesticides in agriculture (that have estrogenic activity), the increased concentration of these chemicals with an estrogenic compound could promote or facilitate development of the disease. Endogenous and exogenous estrogens might play a role as one of the triggering factors or co-factor ("the soil") in these ABDs [52-54].

Thiol compounds or mercaptans cause acantholysis in vivo and in vitro in cultured tissues [20, 40, 55]. Thiol-mediated cell-cell adhesion loss seem to be caused by direct biochemical aberration of desmosome structure itself, e.g. by inhibition of keratinocyte transglutaminase or acetylcholinesterase or forming thiol-cysteine bonds instead of cysteine-cysteine bonds making the protein dysfunctional $[40,56,57]$. However thiols also are reported to activate the proteases, and considered to bind DSGs that results in neoantigen formation that triggers the autoimmunity [57]. Hazardous volatile and waterborne compounds able to be detected in the vicinity of wastewater treatment plants and present in the sludge (semi-solid waste) and sediments usually include volatile thiols [36, 38, 58-60]. There are also industrial "masked thiols", compounds with disulfide bridge (-S-S-), potent into forming an active sulfhydryl (-SH) group during biotransformation, e.g. dimethyl disulfide (DMDS) originating in the wastewater treatment plant from anaerobic fermentation [36, 58, 59], liquid dimethyl trisulfide, present in pemphigus-exacerbating Allium family [61] or bis 1-(methylthio)ethyl disulfide [62]. All of these compounds are theoretically able to trigger a range of pemphigus diseases (mostly PF) via ingestion or topical application due to $(-\mathrm{SH})$ radical [63].

Many other mutagens and neurotoxins can be found in waste disposals and may modulate the immune system: hydrogen sulfide, heavy metals, polycyclic aromatic hydrocarbons, polychlorinated biphenyls, di(2-ethylhexyl) phthalates, polychlorinated dibenzodioxins and dibenzofurans $[38,58]$. The increased skin, hair and nail concentration of mercury, known neurotoxin, was previously shown in fogo selvagem endemic PF patients [16, 64, 65]. Interestingly, antibodies to diverse neural structures were reported to be detected apart from anti-DSG1 antibodies in El-Bagre endemic PF [65]. The link between cholinergic receptors, naturally occurring in neuronal tissue, and antibodies against them detected in pemphigus patients could support the role of mercury compounds in the development of PF/PV autoimmunity.

The odour is a known stressor [66]. People living near the wastewater treatment plant may report irritation, negative mood and health problems that interfere with their daily activities. Moreover, not only are they concerned about the risk to their and their families' health posed by the plant, but also the loss of their property value resulting from unwanted neighbourhood $[67,68]$. Stress is one of the factors listed as triggers of PF/PV [69]. Thus, we cannot exclude its possible role as a common triggering factor in our 3 cases. The mechanism it drives PV/PF autoimmunity is not yet clear, yet could involve an inflammatory process called neurogenic inflammation [70].

The sewage treatment plant officials respond to odour complaints being aware of the inconvenience to neighbouring estates and are taking measures to reduce their level [38]. This policy is an effort to appear more environmental aware and people-orientated. The sludge drying beds, being the source of $77 \%$ of odours, were closed down and grassed in 2011. The other 23\% originate from 4 primary clarifiers (15\%), 6 aeration tanks 
(5\%) and other hermetized facilities (3\%) [38]. The protective domes were installed over the sludge tanks to limit the volatile sulphur-organic compounds. In recent years tree and bush windbreaks were planted on the slope between the sewage treatment plant and the estate to reduce intensiveness of odours emitted. The windbreaks give reduction of spreading odour movement, dispersion and dilution, collection of chemical constituents in wood, leaves and needles, and deposition of aerosols and dusts on the tree barrier on the windward side, reducing their quantity [71]. Although the concentration of phenols and mercaptans are being lowered with coke-oven gas cleaning the performance of these systems is limited, thus constant modernization/alternation to increase the effectiveness of the wastewater treatment is needed [38, $72,73]$. We suspect that topical contact with by-products originating from the wastewater treatment plant followed by systemic absorption might be responsible for the alteration of the skin structure and/or activation of immunological mechanisms leading to blister formation and acantholysis. To our best knowledge, this is the first report investigating the association between pemphigus diseases and vicinity of the wastewater treatment plant.

\section{Conclusions}

The above listed compounds belong to potential inductors of pemphigus autoimmunity. The relation between compound structures, its function groups and precise mechanism by which they act in contribution to pemphigus development remain mostly unknown. As not in every individual exposure to alleged chemical PF/PV is clinically manifesting, the development of autoimmunity might depend on combined genetic/environmental/immunologic predisposition. Due to the rarity of the disease and the existence of only a few studies dealing with the effect of the topical exposure or ingestion on induction of acantholysis, the understanding of the disease is unsatisfactory whereas the hypotheses concerning the role of chemical molecules in pemphigus are based mostly on case reports. Thus, notwithstanding other possible indistinguishable triggers of autoimmunity, we speculate that pemphigus autoimmunity previously suspected to develop after topical exposure or ingestion of culprit chemical compounds might also arise from inhalation of volatile by-products originating from the wastewater treatment plant.

\section{Acknowledgments}

A part of this review was presented as a poster at the $12^{\text {th }}$ EADV Spring Symposium 2015 in Valencia, CD-ROM abstract P158.

\section{Conflict of interest}

The authors declare no conflicts of interest.

\section{References}

1. Pietkiewicz P, Torz M, Gornowicz-Porowska J, et al. Wspótczesne metody leczenia pęcherzycy zwykłej z punktu widzenia początkującego lekarza. Derm Klin 2012; 14: 75-81.

2. Brennan D, Hu Y, Joubeh S, et al. Suprabasal Dsg2 expression in transgenic mouse skin confers a hyperproliferative and apoptosis-resistant phenotype to keratinocytes. J Cell Sci 2007; 120: 758-71.

3. Mannan T, Jing S, Foroushania SH, et al. RNAi-mediated inhibition of the desmosomal cadherin (desmoglein 3) impairs epithelial cell proliferation. Cell Prolif 2011; 44: 301-10.

4. Gornowicz-Porowska J, Bowszyc-Dmochowska M, Seraszek-Jaros A, et al. Loss of correlation between intensities of desmoglein 2 and desmoglein 3 expression in basal cell carcinomas. Acta Dermatovenerol Croat 2011; 19: 150-5.

5. Pietkiewicz P, Gornowicz-Porowska J, Bowszyc-Dmochowska M, et al. Discordant expression of desmoglein 2 and 3 at the mRNA and protein levels in nodular and superficial basal cell carcinoma revealed by immunohistochemistry and fluorescent in situ hybridization. Clin Exp Dermatol 2014; 39: 628-35.

6. Brennan-Crispi DM, Hossain C, Sahu J, et al. Crosstalk between desmoglein 2 and patched 1 accelerates chemicalinduced skin tumorigenesis. Oncotarget 2015; 6: 8593-605.

7. Lanza A, Cirillo N, Rossiello R, et al. Evidence of key role of Cdk2 overexpression in pemphigus vulgaris. J Biol Chem 2008; 283: 8736-45.

8. Cirillo N, Femiano F, Gombos F, Lanza A. High-dose pemphigus antibodies against linear epitopes of desmoglein 3 (Dsg3) can induce acantholysis and depletion of Dsg3 from keratinocytes. Immunol Lett 2009; 122: 208-13.

9. Pisanti S, Sharav Y, Kaufman E, Posner LN. Pemphigus vulgaris: incidence in Jews of different ethnic groups, according to age, sex, and initial lesion. Oral Surg Oral Med Oral Pathol 1974; 38: 382-7.

10. Hietanen J, Salo OP. Pemphigus: an epidemiological study of patients treated in Finnish hospitals between 1969 and 1978. Acta Derm Venereol 1982; 62: 491-6.

11. Langan SM, Smeeth L, Hubbard R, et al. Bullous pemphigoid and pemphigus vulgaris--incidence and mortality in the UK: population based cohort study. BMJ 2008; 337: a180.

12. Marazza G, Pham HC, Schärer L, et al. Incidence of bullous pemphigoid and pemphigus in Switzerland: a 2-year prospective study. Br J Dermatol 2009; 161: 861-8.

13. Ruocco V, Ruocco E, Lo Schiavo A, et al. Pemphigus: etiology, pathogenesis, and inducing or triggering factors: facts and controversies. Clin Dermatol 2013; 31: 374-81.

14. Pietkiewicz P, Gornowicz-Porowska J, Bowszyc-Dmochowska M, Dmochowski M. Malignancy in relation to autoimmune blistering dermatoses: molecular and clinical aspects. In: Highlights in Skin Cancer. Vereecken P (ed). InTech, Rijeka 2013; 159-210.

15. Pietkiewicz P, Gornowicz-Porowska J, Bowszyc-Dmochowska M, Dmochowski M. A retrospective study of antihypertensives in pemphigus: a still unchartered odyssey particularly between thiols, amides and phenols. Arch Med Sci 2015; 11: 1021-7.

16. Robledo MA. Chronic methyl mercury poisoning may trigger endemic pemphigus foliaceus "fogo selvagem". Med Hypotheses 2012; 78: 60-6.

17. Yamagami Y, Kohda M, Mimura S, Ueki H. Pemphigus vulgaris associated with silicosis. Dermatol 1998; 197: 55-7.

18. Haustein UF. Pemphigus vulgaris in association with silicosis. Eur J Dermatol 2000; 10: 614-6. 
19. Ueki H, Takao J, Yamasaki F, et al. Pemphigus foliaceus associated with silicosis. Br J Dermatol 2000; 143: 456-7.

20. Brenner S, Tur E, Shapiro J, et al. Pemphigus vulgaris: environmental factors. Occupational, behavioral, medical, and qualitative food frequency questionnaire. Int J Dermatol 2001; 40: 562-9.

21. Tsankov N, Dimitrowa J, Obreschkowa E, Lasarowa A. Induced pemphigus caused by the pesticide phosphamide. Z Hautkr 1987; 62: 196-201.

22. Tsankov N, Kazandjieva J, Gantcheva M. Contact pemphigus induced by dihydrodiphenyltrichlorethane. Eur J Dermatol 1998; 8: 442-3.

23. Orion E, Barzilay D, Brenner S. Pemphigus vulgaris induced by diazinon and sun exposure. Dermatology 2000; 201: 378-9.

24. Brenner S, Ruocco V, Ruocco E, et al. A possible mechanism for phenol-induced pemphigus. Skinmed 2006; 5: 25-6.

25. Gornowicz-Porowska J, Pietkiewicz P, Bowszyc-Dmochowska M, Dmochowski M. Immunoglobulin G4 is prevailing over immunoglobulin G1 in autoimmunity of pemphigus and bullous pemphigoid: analysis of tissue-bound antibodies in active diseases. Centr Eur J Immunol 2013; 38: 80-91.

26. Wojewódzki Inspektorat Ochrony Środowiska w Poznaniu. Raport o stanie środowiska w Wielkopolsce w roku 2010. Pułtyk M (ed). Wojewódzki Inspektorat Ochrony Środowiska w Poznaniu. Poznań 2011. http://www.bip.umww.pl/ pliki/eradni/3/97/3540/11600/uchwala-xvi-241-2011z.pdf Accessed Feb 14, 2016.

27. Yang WB, Chen WH, Yuan CS, et al. Comparative assessments of VOC emission rates and associated health risks from wastewater treatment processes. J Environ Monit 2012; 14: 2464-74.

28. Yang J, Wang K, Zhao Q, et al. Underestimated public health risks caused by overestimated VOC removal in wastewater treatment processes. Environ Sci Process Impacts 2014; 16 271-9.

29. LeMay J. Docs show history of hazardous waste site in city park near illness cluster. 2012 http://www.mintpressnews. com/city-with-alleged-illness-cluster-has-history-of-leakingcarcinogen/34712/ Accessed Feb 14, 2016.

30. LeMay J. Is an illness cluster in a Minn. suburb killing people before they're 50? 2012 http://www.mintpressnews.com/ is-an-illness-cluster-in-a-minn-suburb-killing-people-beforetheyre-50/32434/ Accessed Feb 14, 2016.

31. LeMay J. Hutchens' crusade: Illness cluster and deaths begs for answers. 2012 http://www.mintpressnews.com/ hutchens-crusade-illness-cluster-and-deaths-begs-for-answers/32656/ Accessed Feb 14, 2016.

32. Queensland Industrial Relations Commission. Workers' Compensation and Rehabilitation Act 2003 - s. 561(1) - appeal against decision of industrial commission Troy John Clarke AND Q-COMP (C/2008/4). The Queensland Government Industrial Gazete 2008; 188: 187-8.

33. Queensland Industrial Relations Commission. Workers Compensation and Rehabilitation Act 2003 - s. 561(1) - appeal against decision of industrial commission Troy John Clarke AND Q-COMP (C/2008/4) (No. 2). The Queensland Government Industrial Gazete 2009; 192: 37-8.

34. Anderson I. Notes of a fatal case of acute pemphigus and gangrene, following a meal of putrid conger eel. Lancet 1873 101: 875.

35. Vanatian B. Dire effect of a putrid eel meal. Ann Improbable Res 2013; 19: 5.

36. Muezzinoglu A. A study of volatile organic sulfur emissions causing urban odors. Chemosphere 2003; 51: 245-52.
37. Jeon EC, Son HK, Sa JH. Emission characteristics and factors of selected odorous compounds at a wastewater treatment plant. Sensors 2009; 9: 311-26.

38. Aquanet. Oddziaływanie COŚ na środowisko. Aquanet 2010. http://www.slideshare.net/Ekokonsultacje/oddziaywanieco-na-rodowisko; Accessed Feb 14, 2016.

39. Kośmider J, Mazur-Chrzanowska B, Wyszyński B. Odory. Wydawnictwo Naukowe PWN, Warsaw 2015.

40. Brenner S, Srebrnik A, Goldberg I. Pemphigus can be induced by topical phenol as well as by foods and drugs that contain phenols or thiols. J Cosmet Dermatol 2003; 2: 161-5.

41. Feliciani C, Ruocco E, Zampetti A, et al. Tannic acid induces in vitro acantholysis of keratinocytes via IL-1alpha and TNFalpha. Int J Immunopathol Pharmacol 2007; 20: 289-99.

42. Tur E, Brenner S. The role of the water system as an exogenous factor in pemphigus. Int J Dermatol 1997; 36: 810-6.

43. Tur E, Brenner S. Diet and pemphigus. In pursuit of exogenous factors in pemphigus and fogo selvagem. Arch Dermatol 1998; 134: 1406-10.

44. Brenner S. Pemphigus and diet. Have we solved the mystery of fogo selvagem? Adv Exp Med Biol 1999; 455: 267-9.

45. Ramos W, Chacon GR, Galarza C, et al. Endemic pemphigus in the Peruvian Amazon: epidemiology and risk factors for the development of complications during treatment. An Bras Dermatol 2012; 87: 838-45.

46. Bolz U, Hagenmaier H, Körner W. Phenolic xenoestrogens in surface water, sediments, and sewage sludge from BadenWürttemberg, south-west Germany. Environ Pollut 2001; 115: 291-301.

47. Ivashechkin P, Corvini PF, Dohmann M. Behaviour of endocrine disrupting chemicals during the treatment of municipal sewage sludge. Water Sci Technol 2004; 50: 133-40.

48. Fernandez MP, Noguerol TN, Lacorte S, et al. Toxicity identification fractionation of environmental estrogens in waste water and sludge using gas and liquid chromatography coupled to mass spectrometry and recombinant yeast assay. Anal Bioanal Chem 2009; 393: 957-68.

49. Liu R, Song S, Lin Y, et al. Occurrence of synthetic phenolic antioxidants and major metabolites in municipal sewage sludge in China. Environ Sci Technol 2015; 49: 2073-80.

50. Veeresh GS, Kumar P, Mehrotra I. Treatment of phenol and cresols in up-flow anaerobic sludge blanket (UASB) process: a review. Water Res 2005; 39: 154-70.

51. Sun $Y$, Huang $H$, Sun $Y$, et al. Ecological risk of estrogenic endocrine disrupting chemicals in sewage plant effluent and reclaimed water. Environ Pollut 2013; 180: 339-44.

52. Pietkiewicz P, Gornowicz-Porowska J, Dmochowski M, Bowszyc-Dmochowska M. Sex hormones: triggers or suppressors of autoimmune bullous dermatoses? EADV Spring Symposium Cracow 2013, Poland, May 23-26 th 2013.

53. Whitacre CC. Sex differences in autoimmune disease. Nat Immunol 2001; 2: 777-80.

54. González DA, Díaz BB, Rodríguez Pérez M del C, et al. Sex hormones and autoimmunity. Immunol Lett 2010; 133: 6-13.

55. Wolf R, Ruocco V. Gaining more insight into the pathomechanisms of thiol-induced acantholysis. Med Hypotheses 1997; 48: 107-10.

56. Dobrosavljević Vukojević D, Stojković Filipović J, Sjerobabin $M$, et al. Lisinopril-induced pemphigus foliaceus in a patient with diabetes mellitus and Kaposi-Juliusberg varicelliform eruption. Serb J Dermatol Venerol 2012; 4: 153-62.

57. Scott DM, Davis D, Soderberg KI. Drug-induced pemphigus. 2012 http://emedicine.medscape.com/article/1063684-overview; Accessed Feb 14, 2016. 
58. Cyprowski M, Krajewski JA. Czynniki szkodliwe dla zdrowia występujące w oczyszczalniach ścieków komunalnych. Med Pr 2003; 54: 73-80.

59. Barczak R. Analiza porównawcza olfaktometrii terenowej z innymi metodami badawczymi w ocenie oddziatywania zapachowego oczyszczalni ścieków. Doctoral dissertation. Warsaw 2014. https://www.depot.ceon.pl/ handle/123456789/6204 Accessed Feb 14, 2016.

60. van Leerdam RC, de Bok FA, Lomans BP, et al. Volatile organic sulfur compounds in anaerobic sludge and sediments: biodegradation and toxicity. Environ Toxicol Chem 2006; 25: 3101-9.

61. Sivret EC, Wang B, Parcsi G, Stuetz RM. Prioritisation of odorants emitted from sewers using odour activity values. Water Res 2016; 88: 308-21.

62. Rajbansi B, Sarkar U, Hobbs SE. Hazardous odor markers from sewage wastewater: a step towards simultaneous assessment, dearomatization and removal. J Taiwan Inst Chem Eng 2014; 45: 1549-57.

63. Schmutz JL, Barbaud A, Trechot P. Indapamide-induced pemphigus foliaceus a sulfurous affair? Ann Dermatol Venereol 2002; 129: 1085.

64. Abréu Vélez AM, Warfvinge G, Herrera WL, et al. Detection of mercury and other undetermined materials in skin biopsies of endemic pemphigus foliaceus. Am J Dermatopathol 2003; 25: 384-91.

65. Abreu-Velez AM, Howard MS, Yi H, et al. Neural system antigens are recognized by autoantibodies from patients affected by a new variant of endemic pemphigus foliaceus in Colombia. J Clin Immunol 2011; 31: 356-68.

66. Asmus CL, Bell PA. Effects of environmental odor and coping style on negative affect, anger, arousal, and escape. J Appl Soc Psychol 1999; 29: 245-60.

67. Wing S, Horton RA, Marshall SW, et al. Air pollution and odor in communities near industrial swine operations. Environ Health Perspect 2008; 116: 1362-8.

68. Horton RA, Wing S, Marshall SW, Brownley KA. Malodor as a trigger of stress and negative mood in neighbors of industrial hog operations. Am J Public Health 2009; 99 (Suppl 3): S610-5.

69. Brenner S, Bar-Nathan EA. Pemphigus vulgaris triggered by emotional stress. J Am Acad Dermatol 1984; 11: 524-5.

70. Black PH. Stress and the inflammatory response: a review of neurogenic inflammation. Brain Behav Immun 2002; 16: 622-53.

71. NRCS Missouri. Using windbreaks to reduce odors associated with livestock production faci. http://www.nrcs.usda.gov/ wps/portal/nrcs/detail/mo/about/?cid=nrcs144p2_012665 Accessed Feb 14, 2016.

72. Kumar MS, Vaidya AN, Shivaraman N, Bal AS. Performance evaluation of a full-scale coke oven wastewater treatment plant in an integrated steel plant. Indian J Environ Health 2003; 45: 29-38.

73. Chakraborty S, Bhattacharya T, Patel TN, Tiwari KK. Biodegradation of phenol by native microorganisms isolated from coke processing wastewater. J Environ Biol 2010; 31: 293-6. 